Article

\title{
Pharmacokinetic, Antiproliferative and Apoptotic Effects of Phenolic Acids in Human Colon Adenocarcinoma Cells Using In Vitro and In Silico Approaches
}

\author{
Lana de Souza Rosa ${ }^{1}$, Nathállia Araújo Jordão ${ }^{1}$, Nathália da Costa Pereira Soares ${ }^{1}$, \\ Joelma Freire de Mesquita ${ }^{2}$, Mariana Monteiro ${ }^{3}$ and Anderson Junger Teodoro ${ }^{4, *(1)}$ \\ 1 Laboratory of Functional Foods, Food and Nutrition Program, UNIRIO, Rio de Janeiro 22290-240, Brazil; \\ lanasrosa@gmail.com (L.d.S.R.); nathalliasomerhalder@gmail.com (N.A.J.); \\ nathy.soares@gmail.com (N.d.C.P.S.) \\ 2 Laboratory of Bioinformatics and Computational Biology, Program Postgraduate in Molecular and Cellular \\ Biology, UNIRIO, Rio de Janeiro 22290-240, Brazil; jomesquita@gmail.com \\ 3 Nutrition Program, Laboratory of Functional Foods, UFRJ, Rio de Janeiro 22290-240, Brazil; \\ macostamonteiro@gmail.com \\ 4 Department of Food Science, Food and Nutrition Program, Federal University of Rio de Janeiro State, Rio de \\ Janeiro. Av. Pasteur, 296-Urca, Rio de Janeiro-RJ 22290-240, Brazil \\ * Correspondence: atteodoro@gmail.com; Tel.: +55-21-25427236; Fax: +55-21-25427752
}

Academic Editor: Francesca Giampieri

Received: 31 August 2018; Accepted: 13 September 2018; Published: 8 October 2018

\begin{abstract}
Colon cancer is the second most common cause of cancer deaths in the USA and Europe. Despite aggressive therapies, many tumors are resistant to current treatment protocols and epidemiological data suggest that diet is a major factor in the etiology of colon cancer. This study aimed to evaluate the antioxidant activity and the influence of 3,4-dihydroxyphenylacetic (3,4-DHPAA), $p$-coumaric ( $p$-CoA), vanillic (VA) and ferulic (FA) acids on cell viability, cell cycle progression, and rate of apoptosis in human colon adenocarcinoma cells (HT-29). The results showed that all compounds tested reduce cell viability in human colon cancer cells. 3,4-DHPAA promoted the highest effect antiproliferative with an increase in the percentage of cells in $G_{0} / G_{1}$ phase, accompanied by a reduction of cells in $\mathrm{G}_{2} / \mathrm{M}$ phase. Cell cycle analysis of VA and FA showed a decrease in the proportion of cells in $\mathrm{G}_{0} / \mathrm{G}_{1}$ phase $(10.0 \mu \mathrm{M}$ and $100.0 \mu \mathrm{M})$. $p$-CoA and FA acids increased the percentage of apoptotic cells and non-apoptotic cells. 3,4-DHPAA seems to be the substance with the greatest potential for in vivo studies, opening thus a series of perspectives on the use of these compounds in the prevention and treatment of colon cancer.
\end{abstract}

Keywords: phenolic acid; colon cancer; cell cytotoxicity

\section{Introduction}

Colon cancer is the second most prevalent malignancy and the third leading cause of cancer-related mortalities worldwide, resulting in $\sim 500,000$ mortalities every year [1]. Approximately, 1 million new cases are diagnosed every year [2]. In general, colon cancer is related to environmental factors, mainly dietary, genetic predisposition and obesity, among other factors [3]. Colon cancer develops through a multistage process that could be recognized at a histopathological level by progression from mucosa to invasive carcinoma [4].

Epidemiological data suggest that diet is a major factor in the etiology of colon cancer. High consumption of red meat, animal fat, alcohol and refined cereals is linked to higher incidence of 
these cancers in Western societies, whereas protective effects of fruits, vegetables and whole grains have been suggested [5].

A wide variety of fruits and vegetables provides a range of nutrients and different bioactive compounds including phytochemicals (phenolics, flavonoids, and carotenoids), vitamins (vitamin C, folate, and pro-vitamin A), minerals (potassium, calcium, and magnesium), and fibers [6]. Phenolic compounds have been reported to possess important biological properties such as anticancer, antiviral, antioxidant and anti-inflammatory activities [7]. Phenolics are compounds possessing one or more aromatic rings with one or more hydroxyl groups and generally. It has been generally classified as subgroups of phenolic acids, flavonoids, stilbenes, coumarins, and tannins [6].

Ferulic acid (FA) and para-coumaric acid ( $p$-CoA), members of the hydroxycinnamic acid family, are the main phenolic compounds in cereal bran, one of the major fiber sources in a healthy diet [8]. $p$-CoA is the most abundant isomer of cinnamic acid, widely found in edible plants such as peanuts, tomatoes, carrots. $p$-CoA is reported to have antitumor and anti-mutagenic activities [9]. Vanillic acid, a benzoic acid derivative, is an oxidized form of vanillin produced during the conversion of vanillin into ferulic acid. Vanillic acid is one of the major components of "natural vanilla" aroma and it is used as a flavoring agent. It has also an antioxidant and antimicrobial activity and therefore it can be considered as a potential food preservative $[10,11]$. Colonic bacteria can convert flavonoids into large number of simple phenolic acids that can be absorbed into the circulation, and exert biological effects in the body. Previous publication indicated that quercitin is metabolized to 3-hydroxyphenylacetic acid, 3,4-dihydroxybenzoic acid. 3,4-dihydroxyphenylacetic acid, whose structure is analogous to that of caffeic acid, but it lacks a double bond in the aliphatic chain. It also exerts anti-oxidant properties, antiplatelet activity and anxiolytic activity $[12,13]$.

A range of evidence supports the theory of anticancer properties of phenolic acids, although the mechanisms are still not fully understood, but may include scavenging free radicals, induction of enzymes involved in the metabolism of xenobiotics, regulation of gene expression, modulation of cellular signaling pathways including those involved in DNA damage repair, cell proliferation, apoptosis and invasion [14]. Phenolic acids have been reported to inhibit transcription factors linked to inflammation, pro-inflammatory cytokines, COX-2, lipoxygenases (LOX), inducible nitric oxide synthase (iNOS) [14]. Therefore, this study aimed to evaluate the antioxidant activity and the influence of 3,4-dihydroxyphenylacetic (3,4-DHPAA), $p$-coumaric ( $p$-CoA), vanillic (VA) and ferulic (FA) acids on cell viability, cell cycle progression, and rate of apoptosis in human colon adenocarcinoma cells (HT-29).

\section{Results}

\subsection{Antioxidant Activity and In Silico Approach of 3,4-DHPAA, p-CoA, VA and FA}

All compounds were analyzed by the DPPH method at concentrations below $25.0 \mu \mathrm{M}$ (Table 1), where it is observed that there was no significant reduction of the DPPH radical (results not shown). After 30 min of testing, the percent reduction of DPPH tended to stabilize at the concentration of $25.0 \mu \mathrm{M}$. It was observed in the same method, that the 3,4-DHPAA presented the highest percentage of reduction of the radical, followed by VA, FA and $p$-CoA.

The ORAC assay (Table 1) revealed that $p$-CoA and 3,4-DHPAA showed the highest antioxidant, followed by VA and FA. 3,4-DHPAA and VA showed higher antioxidant activity compared to FA and $p$-CoA by FRAP assay, corroborating with the results observed in the DPPH assay. All compounds were also shown to be significantly different at all concentrations studied $(p \leq 0.05)$. In the ABTS assay (Table 1), 3,4-DHPAA showed the highest antioxidant activity, as well as in the DPPH and FRAP assay. 
Table 1. Comparison between pKCSM and LAZAR toxicity prediction, and antioxidant activity of phenolic acids.

\begin{tabular}{|c|c|c|c|c|c|c|}
\hline Parameters & & 3,4-DHPAA & $p$-CoA & VA & FA & Unit \\
\hline \multirow{2}{*}{$\begin{array}{l}\text { AMES } \\
\text { toxicity }\end{array}$} & pkCSM & No & No & No & No & \multirow{2}{*}{ Categorical (Yes/No) } \\
\hline & LAZAR & No & No & No & Yes & \\
\hline \multirow{2}{*}{ Hepatotoxicity } & pkCSM & No & No & No & No & Categorical (Yes/No) \\
\hline & LAZAR & 0.246 & - & & - & NA \\
\hline \multirow{2}{*}{$\begin{array}{l}\text { Oral Rat Acute } \\
\text { Toxicity (LD50) }\end{array}$} & pkCSM & 1.871 & 1.963 & 2.004 & 1.954 & Numeric (mol/kg) \\
\hline & LAZAR & - & - & - & - & NA \\
\hline \multirow{2}{*}{$\begin{array}{l}\text { Oral Rat Chronic } \\
\text { Toxicity (LOAEL) }\end{array}$} & pkCSM & 3.045 & 2.94 & 2.827 & 2.892 & $\begin{array}{c}\text { Numeric } \\
\text { (log mg/kg_bw/day) }\end{array}$ \\
\hline & LAZAR & - & - & - & - & NA \\
\hline \multirow{2}{*}{$\begin{array}{l}\text { Carcinogenicity } \\
\text { (rat) }\end{array}$} & pkCSM & - & - & - & - & NA \\
\hline & LAZAR & No & No & No & No & Categorical (Yes/No) \\
\hline \multirow{2}{*}{$\begin{array}{l}\text { Carcinogenicity } \\
\text { (mouse) }\end{array}$} & pkCSM & - & - & - & - & NA \\
\hline & LAZAR & No & No & No & No & Categorical (Yes/No) \\
\hline \multirow{2}{*}{$\begin{array}{l}\text { Carcinogenicity } \\
\text { (rodents) }\end{array}$} & pkCSM & - & - & - & - & NA \\
\hline & LAZAR & No & No & Yes & Yes & Categorical (Yes/No) \\
\hline \multirow{2}{*}{$\begin{array}{l}\text { Max. tolerated } \\
\text { dose (human) }\end{array}$} & pkCSM & 1.453 & 1.505 & 1.404 & 1.366 & $\begin{array}{c}\text { Numeric } \\
(\log \mathrm{mg} / \mathrm{kg} / \text { day })\end{array}$ \\
\hline & LAZAR & 1.66 & 0.145 & 5.7 & 2.94 & Numeric (mg/kg_bw/day) \\
\hline \multicolumn{2}{|c|}{ DPPH $(25.0 \mu \mathrm{M})$} & 93.84 & 11.77 & 16.40 & 14.35 & DPPH reduction (\%) \\
\hline \multicolumn{2}{|c|}{ FRAP $(5.0 \mu \mathrm{M})$} & 970.62 & 33.06 & 240.56 & 141.39 & $\begin{array}{l}\text { ( } \mu \mathrm{Mol} \text { Ferrous Sulfate } / \mu \mathrm{mol} \text { of } \\
\text { compound) }\end{array}$ \\
\hline \multicolumn{2}{|c|}{ ABTS $(5.0 \mu \mathrm{M})$} & 3044.75 & 1879.75 & 1376.00 & 2387.25 & $\begin{array}{l}\text { ( } \mu \mathrm{Mol} \text { Trolox } / \mu \mathrm{mol} \text { of } \\
\text { compound) }\end{array}$ \\
\hline \multicolumn{2}{|c|}{ ORAC $(3.0 \mu \mathrm{M})$} & 12.9 & 15.0 & 11.7 & 4.73 & $\begin{array}{l}\text { (meq Trolox } / \mathrm{mol} \text { of } \\
\text { compound) }\end{array}$ \\
\hline
\end{tabular}

NA-not applicable.

The predictive results (Table 1) presented by pkCSM and LAZAR algorithms were compared and presented in Table 1. Both predictive strategies suggested 3,4-DHPAA, $p$-CoA and VA were non-mutagenic in the Ames toxicity test, although the predictive results using the in silico approach indicated the absence of mutagenicity in Ames test, in FA. pkCSM and LAZAR prediction did not suggest a carcinogenic effect of any of the compounds in mice and rats separately. However, VA and FA had suggested carcinogenic effect in rats by pkCSM and LAZAR prediction. The maximum tolerated dose in humans were predicted in the same range using both strategies.

\subsection{Effect of 3,4-DHPAA, $p$-CoA, VA and FA in Cell Viability}

The dye exclusion test is used to determine the number of viable cells present in a cell suspension. It is based on the principle that live cells possess intact cell membranes that exclude certain dyes, such as Trypan Blue. In this test, a cell suspension is mixed merely with dye and then visually examined to determine whether cells take up or exclude dye. Cells treated with 3,4-DHPAA, $p$-CoA, VA and FA presented a percentage reduction in cell viability at $1.0 \mu \mathrm{M}$ with a significant difference $(p<0.05)$ when compared to control cells. At the concentration of $10.0 \mu \mathrm{M}$ the cells treated with 3,4-DHPAA presented the highest percentage of reduction of cell viability, followed by $p$-CoA, FA and VA with significant difference $(p<0.01)$ when compared to the control group (Figure 1). 
(A)

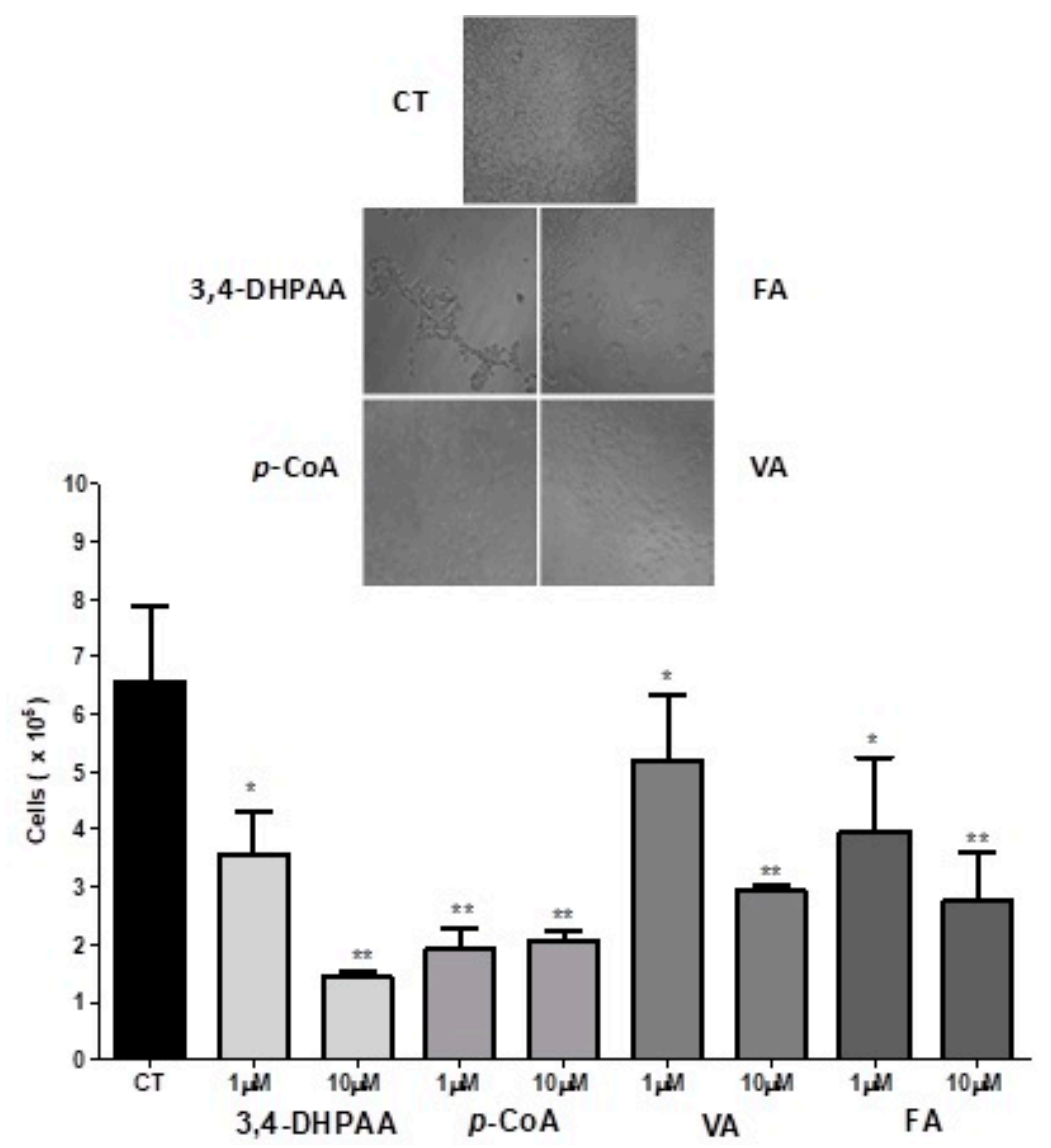

Figure 1. Effect of 3,4-DHPAA, $p$-CoA, VA and FA $(100 \mu \mathrm{M})$ on HT-29 cells $24 \mathrm{~h}$ after incubation (A). Effect of 3,4-DHPAA, $p$-CoA, VA and FA on cell viability (mean \pm SD) (HT-29) $24 \mathrm{~h}$ after incubation (B). Significant differences between the untreated cells (CT) and those incubated with the respective acids $(1.0 \mu \mathrm{M}$ and $10.0 \mu \mathrm{M})$ were compared by the one-way ANOVA test, with Tukey post-test $\left({ }^{*} p<0.05\right.$; ** $p<0.01)$.

HT-29 cells were seeded and after recovery for $24 \mathrm{~h}$, cells were incubated with $0.1 \mu \mathrm{M}$ to $100.0 \mu \mathrm{M}$ of 3,4-DHPAA, $p$-CoA, VA and FA during $24 \mathrm{~h}$. We used the MTT assay to monitor the cell viability. 3,4-DHPAA did not change the cellular growth profile at concentrations of $0.1 \mu \mathrm{M}$ and $1.0 \mu \mathrm{M}$. A more significant dose-dependent decrease $(66.0 \%)$ was identified in cells treated with concentrations higher than or equal to $10.0 \mu \mathrm{M}$ of 3,4-DHPAA (Figure 2A). FA showed an inhibitory growth effect of viable cells when compared to control after treatment with all concentrations tested. FA promoted on average inhibition of $63.0 \%$ of cells treated with $2.5 \mu \mathrm{M}$ to $100.0 \mu \mathrm{M}$ (Figure 2B) When HT-29 cells were incubated with $p$-CoA, a significant reduction of HT-29 viable cells was observed, with an average reduction of $40.0 \%$ and without any significant difference between these concentrations $(p>0.05$, Figure $2 \mathrm{C})$. No effect was shown after VA treatment with lower doses $(0.1 \mu \mathrm{M}$ to $1.0 \mu \mathrm{M})$, however, high concentrations of VA $(2.5 \mu \mathrm{M}$ to $100.0 \mu \mathrm{M})$ inhibited cell viability with an average inhibition of $23 \%$ without difference among the concentrations tested $(p>0.05)$ (Figure 2D). 

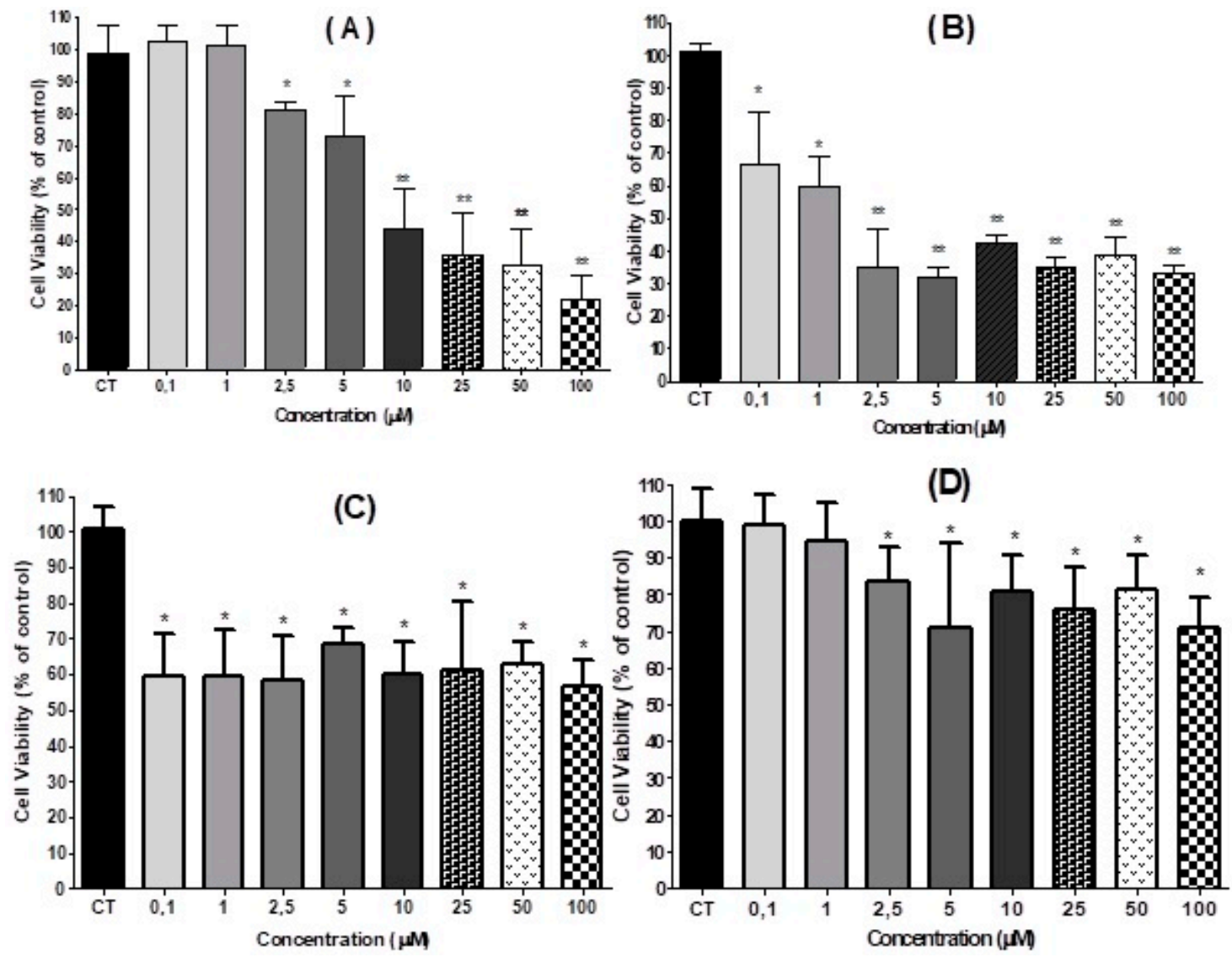

Figure 2. Effect of 3,4-DHPAA (A), FA (B), $p$-CoA (C) and VA (D) on viability (mean \pm SD) of HT-29 cells $24 \mathrm{~h}$ after incubation. Significant differences between the untreated cells (CT) and those incubated with the respective acids $(0.1 \mu \mathrm{M}$ to $100 \mu \mathrm{M})$ were compared by the One-way ANOVA test, with Tukey post-test $\left({ }^{*} p<0.05 ;{ }^{* *} p<0.01\right)$.

\subsection{Effect of 3,4-DHPAA, $p$-CoA, VA and FA in Cell Cycle Progression}

To monitor the influence of 3,4-DHPAA, $p$-CoA, VA and FA on the cell cycle, the cells were incubated with $10.0 \mu \mathrm{M}$ and $100.0 \mu \mathrm{M}$ concentrations of each compound for $24 \mathrm{~h}$ and the percentage of viable cells in different cell cycle phases were quantified. In HT-29 cells, 3,4-DHPAA (10.0 $\mu \mathrm{M}$ and $100.0 \mu \mathrm{M})$ induced an increase in the percentage of cells in $\mathrm{G}_{0} / \mathrm{G}_{1}$ phase followed by a decreased cell number in $\mathrm{S}$ phase $(p<0.05)$ (Figure 3A,B).

3,4-DHPAA $(100 \mu \mathrm{M})$ treatment also promoted a decrease of cells in $\mathrm{G}_{2} / \mathrm{M}$ phase when compared to the control group $(p<0.05)$. $p$ - $\mathrm{CoA}(10.0 \mu \mathrm{M}$ and $100.0 \mu \mathrm{M})$ promoted a significant decrease in $\mathrm{G}_{0} / \mathrm{G}_{1}$ and $\mathrm{S}$ phases, followed by a cell cycle arrest in $\mathrm{G}_{2} / \mathrm{M}$ phase when compared to untreated cells (Figure $3 \mathrm{~A}, \mathrm{C}$ ).

A decrease in the percentage of HT-29 cells in $\mathrm{G}_{0} / \mathrm{G}_{1}$ phase was observed after FA (10 $\mu \mathrm{M}$ and $100 \mu \mathrm{M})$ incubation. A reduction of cells in $S$ phase and a higher percentage of cells in the $\mathrm{G}_{2} / \mathrm{M}$ phase was noted after treatment with FA at $10.0 \mu \mathrm{M}$ and $100.0 \mu \mathrm{M}$, respectively (Figure 4A,B). VA $(10 \mu \mathrm{M}$ and $100 \mu \mathrm{M}$ ) induced a decreased in the percentage of cells in $\mathrm{G}_{0} / \mathrm{G}_{1}$ phase, followed by an increase of cell number in $S$ and $G_{2} / M$ phases when compared to control group $(p<0.05$, Figure $4 A, C)$. 


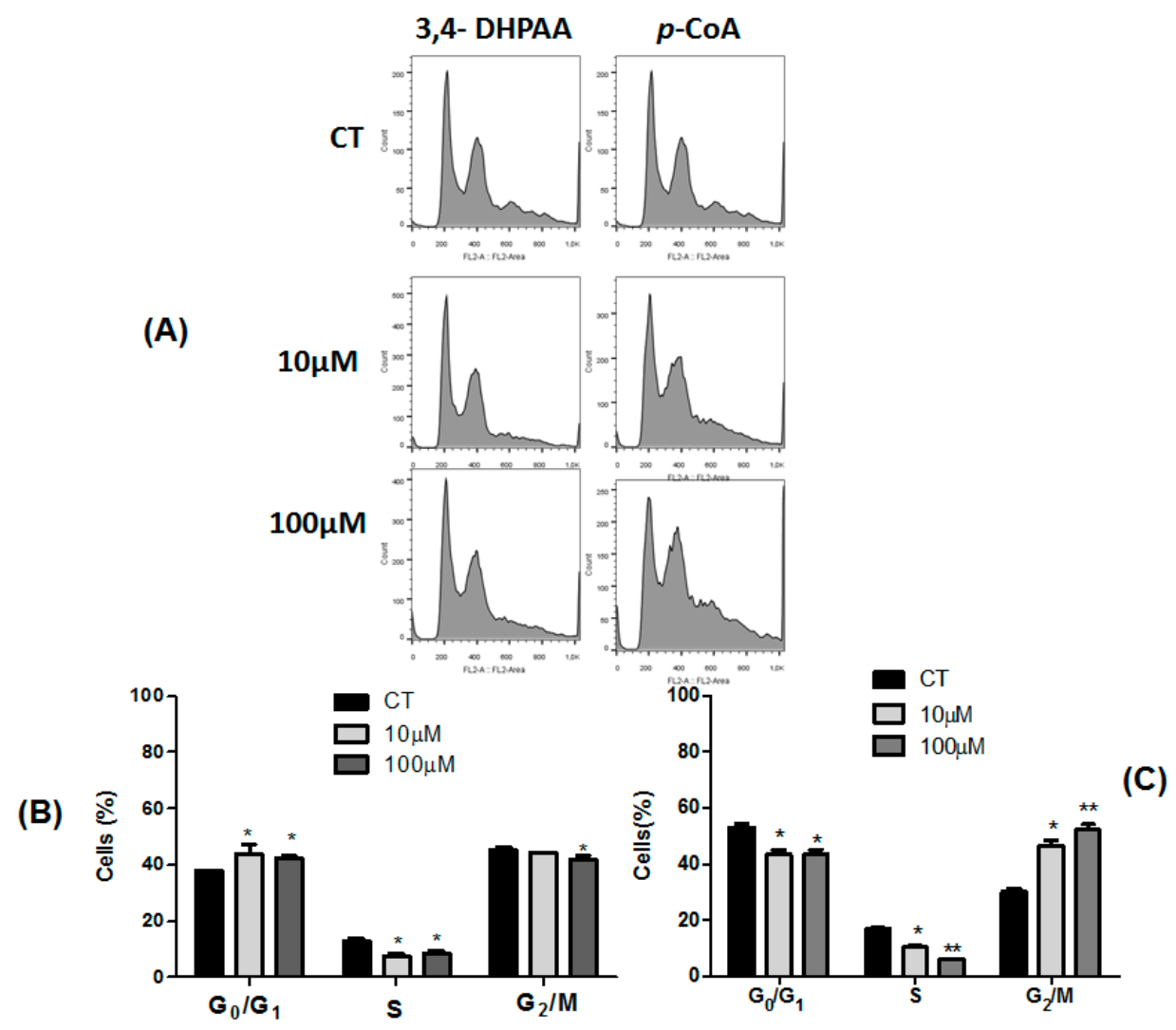

Figure 3. Effect of 3,4-DHPAA and p-CoA on cell cycle progression in HT-29 cells $24 \mathrm{~h}$ after incubation. The phases of the cell cycle are illustrated at control (CT) and treated with $10.0 \mu \mathrm{M}$ and $100.0 \mu \mathrm{M}$ of these compounds in figure (A). The quantitative results of the effect of 3,4-DHPAA compound on this cell line are shown in figure (B) and $p$-CoA in figure (C). The experiment is expressed as mean \pm SD. Significant differences between untreated and treated $(10 \mu \mathrm{M}$ and $100 \mu \mathrm{M})$ cells were compared by the One-way ANOVA test, with Tukey posttest $\left.{ }^{*} p<0.05 ;{ }^{* *} p<0.01\right)$.

(FA)

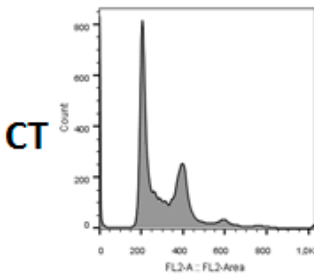

(A) $\quad 10 \mu \mathrm{M}$

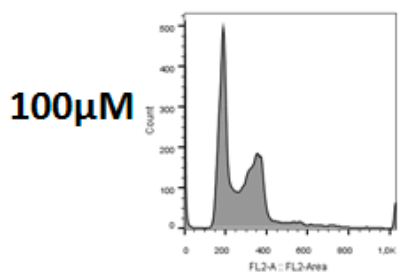

(VA)
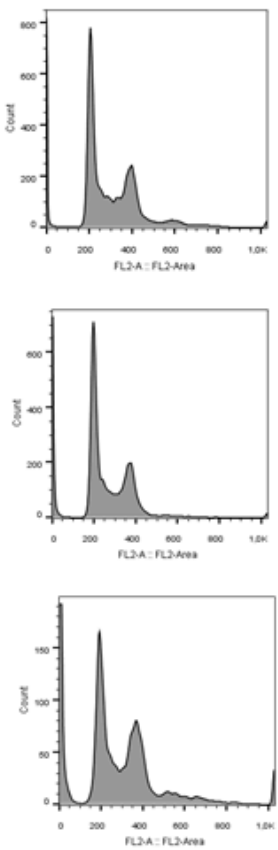

Figure 4. Cont. 
(B)
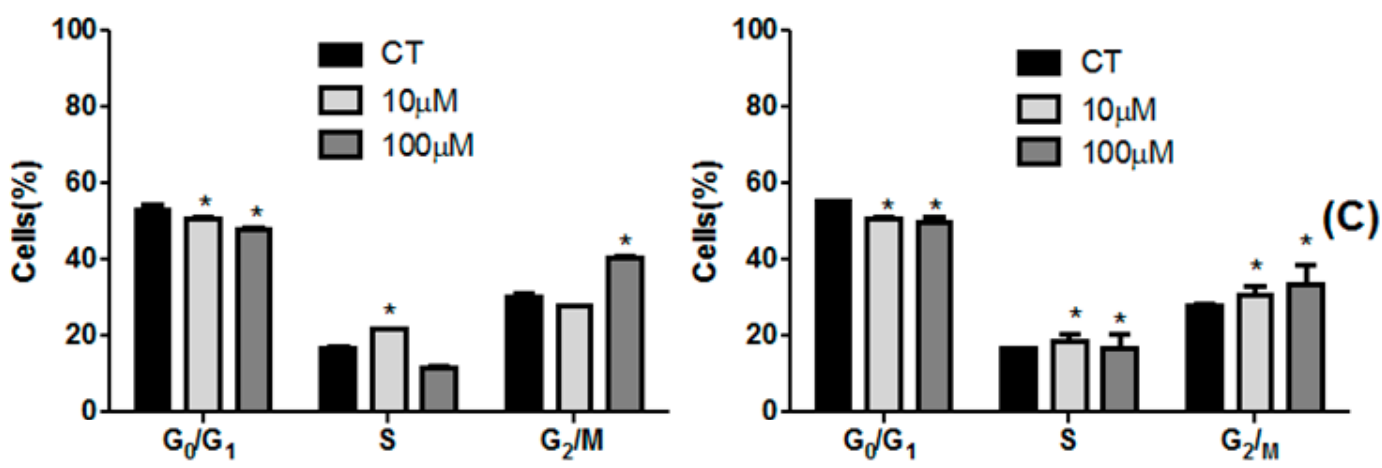

Figure 4. Effect of FA and VA on cell cycle progression in HT-29 cells $24 \mathrm{~h}$ after incubation. The phases of the cell cycle are illustrated at control (CT) and treated with $10 \mu \mathrm{M}$ and $100 \mu \mathrm{M}$ of these compounds in figure (A). The quantitative results of the effect of FA compound on this cell line are shown in figure (B) and VA in figure (C). The experiment is expressed as mean \pm SD. Significant differences between untreated and treated $(10 \mu \mathrm{M}$ and $100 \mu \mathrm{M})$ cells were compared by the One-way ANOVA test, with Tukey posttest $\left({ }^{*} p<0.05\right)$.

\subsection{Effect of 3,4-DHPAA, $p$-CoA, VA and FA in Apoptosis}

We examined next the effect of 3,4-DHPAA, $p$-CoA, VA and FA on different stages of the HT-29 cell death process for $24 \mathrm{~h}$. Table 2 shows the percentages of viable, early apoptotic, late apoptotic, and non-apoptotic cells after treatment with 3,4-DHPAA, $p$-CoA, VA and FA $(10.0 \mu \mathrm{M}$ and $100.0 \mu \mathrm{M})$ and Figure 5 shows the influence of 3,4-DHPAA, $p$-CoA, VA and FA on the apoptosis rate. A significant decrease $(p<0.05)$ in the percentages of viable cells $(10.0 \mu \mathrm{M}$ and $100.0 \mu \mathrm{M})$ and significant increase $(p<0.05)$ in the percentages of apoptotic cells $(100.0 \mu \mathrm{M})$ was observed after treatment with 3,4-DHPAA compared to untreated cells (control group). The percentage of non-apoptotic cells showed an increase $(p<0.05)$ after treatment with 3,4-DHPAA $(10.0 \mu \mathrm{M}$ and $100.0 \mu \mathrm{M}$, Table 2$)$.

Table 2. Effect of 3,4-DHPAA, p-CoA, VA e FA $(10.0 \mu \mathrm{M}$ and $100.0 \mu \mathrm{M})$ on stages of death process in human colon adenocarcinoma cells (HT-29) after $24 \mathrm{~h}$.

\begin{tabular}{|c|c|c|c|c|c|}
\hline Compounds & & $\begin{array}{c}\text { Viable Cells } \\
\text { (Annexin V - } \\
\text { PI-) }\end{array}$ & $\begin{array}{c}\text { Early Apoptosis } \\
\text { (Annexin V + } \\
\text { PI-) }\end{array}$ & $\begin{array}{c}\text { Late Apoptosis } \\
\text { (Annexin V+ } \\
\text { PI+) }\end{array}$ & $\begin{array}{c}\text { Non-Apoptotic } \\
\text { Cells } \\
\text { (Annexin V - PI+) }\end{array}$ \\
\hline \multirow{3}{*}{ 3,4-DHPAA } & $\mathrm{CT}$ & $89.75 \pm 0.13^{a}$ & $3.87 \pm 1.33^{\mathrm{a}}$ & $3.97 \pm 0.26^{\mathrm{a}}$ & $0.17 \pm 0.02^{\mathrm{a}}$ \\
\hline & $10 \mu \mathrm{M}$ & $87.90 \pm 1.04^{b}$ & $5.49 \pm 0.28^{b}$ & $5.84 \pm 1.48^{\mathrm{a}, \mathrm{b}}$ & $2.41 \pm 2.06^{b}$ \\
\hline & $100 \mu \mathrm{M}$ & $85.20 \pm 0.57^{c}$ & $6.93 \pm 1.21^{b}$ & $7.69 \pm 0.80^{b}$ & $0.78 \pm 0.35^{\mathrm{c}}$ \\
\hline \multirow{3}{*}{$p$-CoA } & CT & $92.50 \pm 0.28^{a}$ & $2.08 \pm 0.23^{a}$ & $2.98 \pm 0.04^{\mathrm{a}}$ & $2.45 \pm 0.47^{\mathrm{a}}$ \\
\hline & $10 \mu \mathrm{M}$ & $76.95 \pm 0.64^{b}$ & $12.75 \pm 0.49^{b}$ & $9.83 \pm 0.16^{b}$ & $0.48 \pm 0.06^{b}$ \\
\hline & $100 \mu \mathrm{M}$ & $89.40 \pm 1.48^{c}$ & $0.17 \pm 0.10^{c}$ & $1.38 \pm 0.24^{\mathrm{c}}$ & $6.01 \pm 1.11^{c}$ \\
\hline \multirow{3}{*}{ VA } & $\mathrm{CT}$ & $92.50 \pm 0.28^{a}$ & $2.08 \pm 0.23^{a}$ & $2.98 \pm 0.04^{\mathrm{a}}$ & $2.45 \pm 0.47^{\mathrm{a}}$ \\
\hline & $10 \mu \mathrm{M}$ & $90.00 \pm 4.10^{\mathrm{a}}$ & $0.34 \pm 0.14^{b}$ & $0.93 \pm 0.62^{b}$ & $8.74 \pm 3.34^{b}$ \\
\hline & $100 \mu \mathrm{M}$ & $91.10 \pm 2.83^{a}$ & $0.09 \pm 0.11^{b}$ & $1.00 \pm 0.03^{b}$ & $7.84 \pm 2.88^{b}$ \\
\hline \multirow{3}{*}{ FA } & $\mathrm{CT}$ & $92.50 \pm 0.28^{a}$ & $2.08 \pm 0.23^{a}$ & $2.98 \pm 0.04^{\mathrm{a}}$ & $2.45 \pm 0.47^{\mathrm{a}}$ \\
\hline & $10 \mu \mathrm{M}$ & $82.70 \pm 1.27^{b}$ & $8.28 \pm 1.53^{b}$ & $7.52 \pm 1.68^{b}$ & $1.51 \pm 1.10^{b}$ \\
\hline & $100 \mu \mathrm{M}$ & $89.90 \pm 1.84^{c}$ & $0.48 \pm 0.07^{\mathrm{a}}$ & $1.70 \pm 0.18^{\mathrm{a}}$ & $8.20 \pm 2.28^{c}$ \\
\hline
\end{tabular}

After treatment with $p$-CoA $(10.0 \mu \mathrm{M})$, HT-29 cells showed a decrease in the population of viable cells $(p<0.05)$ and an increase of apoptotic cells (early and late apoptotic cells) compared to control group. The percentage of viable cells did not change significantly $(p>0.05)$ after treatment with VA $(10.0 \mu \mathrm{M}$ and $100.0 \mu \mathrm{M})$ compared to untreated cells. However, a significant difference in the percentage of cells in apoptosis (early and late apoptotic cells), compared to control (Table 2) was 
observed. After treatment with FA $((10.0 \mu \mathrm{M}$ and $100.0 \mu \mathrm{M})$, HT-29 cells showed a decrease in the population of viable cells $(p<0.05)$ compared to control group. Also, when they were incubated with $p$-CoA $(100.0 \mu \mathrm{M})$, VA $((10.0 \mu \mathrm{M}$ and $100.0 \mu \mathrm{M})$ and FA $(100.0 \mu \mathrm{M})$, the HT-29 cells showed an enhanced number of non-apoptotic cells, indicating a probable toxic effect at high doses of these compounds (Table 2 and Figure 5).

Relative apoptosis rate data show that only $p$-CoA and FA acids promoted increased apoptosis after incubation with the lower dose $(10.0 \mu \mathrm{M})$. No effect $(p>0.05)$ was observed after treatment with 3,4-DHPAA and VA $(10.0 \mu \mathrm{M}$ and $100.0 \mu \mathrm{M}$, Figure 5).
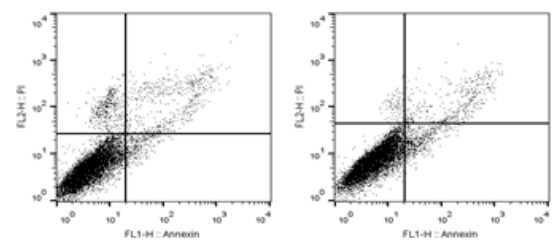

(3,4- DHPAA)

(A)
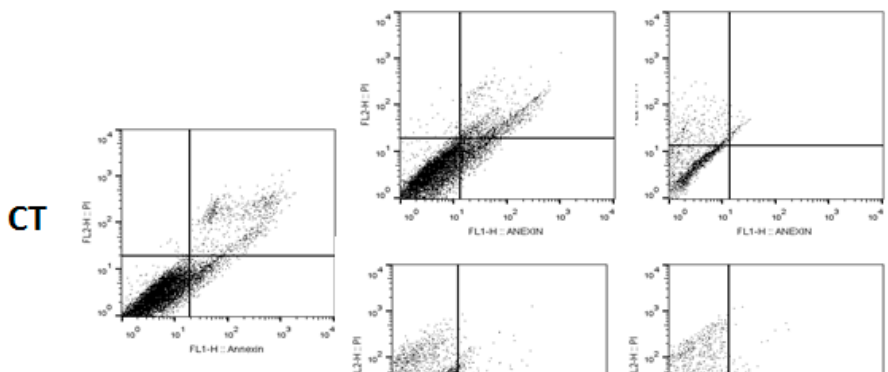

$(p-\operatorname{CoA})$
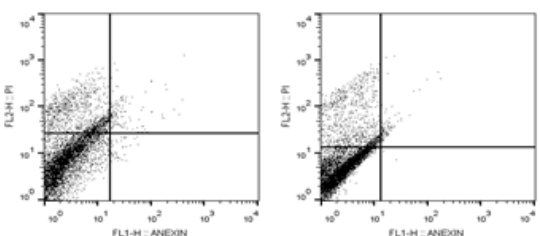

(VA)
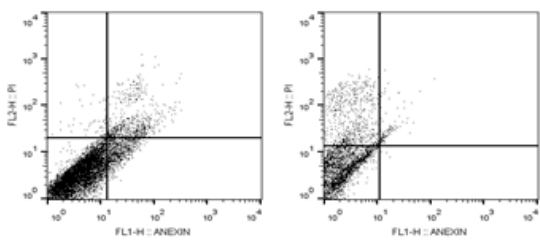

$10 \mu \mathrm{M}$

$100 \mu \mathrm{M}$

(B)

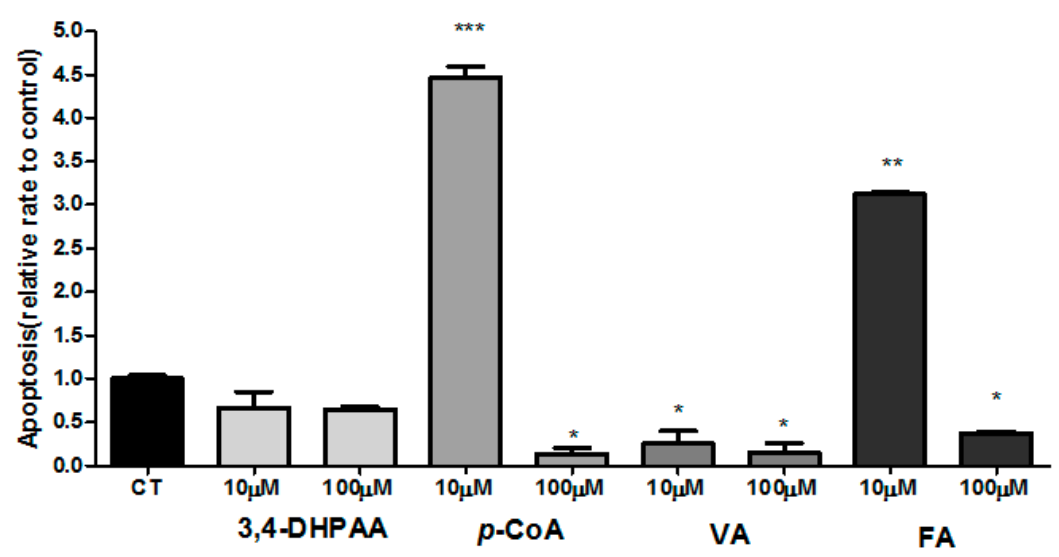

Figure 5. Effect of 3,4-DHPAA, $p$-CoA, FA and VA on rate of apoptosis in HT-29 cells after $24 \mathrm{~h}$ after incubation. Flow cytometry analysis of 3,4-DHPAA, $p$-CoA, FA and VA are illustrated in (A) according to the exposure time and concentration of these compounds. (B) The quantitative effects of 3,4-DHPAA, $p$-CoA, FA and VA on HT-29 cells are after $24 \mathrm{~h}$ exposure. The experiment is expressed as mean $\pm \mathrm{SD}$, with significant differences between untreated cells (CT) and treated (10.0-100.0 $\mu \mathrm{M})$ compared by ANOVA followed by Tukey post-hoc test. * $p<0.05$. 


\section{Discussion}

Some naturally occurring phenolic acids and analogs are known to display a wide variety of biological functions, in addition to their primary antioxidant activity, which is mainly related to modulation of carcinogenesis. Indeed, many phenolic compounds have been investigated for their potential use as cancer chemopreventive agents [15]. The results of the present study provide supporting evidence supporting the role of 3,4-DHPAA, $p$-CoA, VA and FA in the prevention and treatment of colon cancer.

In our study, the antioxidant activity of 3,4-DHPAA, p-CoA, VA and FA was analyzed by four different methods. For the four methods used, the high antioxidant activity of the compounds was observed. It was observed in our study that 3,4-DHPAA showed to have an antioxidant activity superior to the other phenolic acids by DPPH, FRAP and ABTS assays.

Monagas et al. [16] observed that 3,4-DHPAA derived from microbial phenolic metabolites inhibited the secretion of pro-inflammatory cytokines (TNF- $\alpha$, IL-1b and IL-6) in lipopolysaccharide-stimulated peripheral blood mononuclear cells in healthy volunteers. These results indicate that dihydroxylated phenolic acids derived from microbial metabolism present marked anti-inflammatory properties, providing additional information about the health benefits of dietary polyphenols and their potential value as therapeutic agents.

Antioxidant assays (FRAP and DPPH) demonstrated that VA presented the second highest antioxidant potential. In the ABTS and ORAC assay, VA presented a lower antioxidant activity, when compared to the other compounds. The results found in our study are similar to those reported by Tai et al. [17]. When analyzing the antioxidant activity of VA by DPPH, ORAC and ABTS Tai et al. [17] observed that VA was able to repress the three radicals. In the ORAC assay, VA showed a partial inhibition over time in the fluorescence decay profile and a significant depletion of the ABTS radical.

Kiliç and Yesiloglu [18], showed in their study that $p$-CoA had an effective DPPH scavenging, ABTS scavenging and ferric ions $\left(\mathrm{Fe}^{3+}\right)$ reducing power, suggesting that $p$-CoA can be used in the pharmacological and food industry because of these properties. In our results, we can observe that $p$-CoA showed high antioxidant activity by the ORAC method and a lower activity by the other methods FA demonstrated a high antioxidant activity by ABTS assay. The FA provides hydrogen for the neutralization of the free radicals combated, which gives it antioxidant effect.

A range of analytical methods for the determination of antioxidant properties of phenolic compounds is available. Our work demonstrates that different assay methods differ from one another regarding reaction mechanisms, oxidant species, reaction conditions and the way the final results were expressed. A number of antioxidant assays, such as DPPH, ABTS, ORAC, FRAP and TEAC, are commonly used. In a few cases, biological assays, typically involving cell culture, also provide useful information on the effectiveness of antioxidants. The methods used in our study to evaluate the antioxidant activity of these compounds were satisfactory and adequate. These methods are important because free radicals and reactive oxygen species (ROS) have been implicated in contributing to the processes of aging and disease. Our data confirmed what is already described in the literature regarding the high antioxidant activity of 3,4-DHPAA, $p$-CoA, VA and FA.

Cancer is characterized by deregulation of apoptosis, cell proliferation, invasion, angiogenesis and metastasis. It is desirable that there be a compound capable of inhibiting the proliferation of cancer cells. Cell viability inhibition by 3,4-DHPAA, $p$-CoA, VA and FA has already been described in other studies. Gao et al. [19] studied the effects of phenolic acid products formed during colon digestion from green tea, black tea, citrus fruit with rutin or soy digested under the same conditions using pooled human colonic microbiota. Only 3,4-DHPAA exhibited antiproliferative activity in prostate and colon cancer cells. 3,4-DHPAA was significantly $(p<0.005)$ more inhibitory in colon cancer cells (HCT116) compared with an immortalized normal intestinal epithelial cell line (IEC6) with $\mathrm{IC}_{50} 90 \mu \mathrm{mol} / \mathrm{L}$. The antiproliferative activity of 3,4-DHPAA may be due to its catechol structure [20].

Henning et al. [21] found similar results which reported that the plasma concentration of 3,4-DHPAA increased after the black tea intake when tested in vitro. It has been described that 
3,4-DHPAA exercise antiproliferative activity in colon cancer cells (HCT116). Our results demonstrated that 3,4-DHPAA promoted a significant reduction in the percentage of viable cells, around $66 \%$ at concentrations equal to or higher than $10 \mu \mathrm{M}$ after $24 \mathrm{~h}$ incubation.

FA promoted a significant reduction $(35.0 \%)$ in cell viability after treatment with concentrations of 0.1 and $1.0 \mu \mathrm{M}$. Likewise, a higher reduction $(63.0 \%)$ was observed at concentrations equal to or greater than $5.0 \mu \mathrm{M}$. Previous studies using FA demonstrated an inhibitory effect on cell viability on colon cancer cells [22]. This effect was confirmed by in vivo tests in rats by Hudson et al. [23]. The potential health benefits of ferulic acid and other hydroxycinnamic acids have been related mostly to their effective antioxidant activity. Hydroxycinnamic acids can protect low-density lipoprotein (LDL) from oxidative modifications and thereby reduce atherogenesis. They also exhibit inhibitory effects on tumor promotion and can block the formation of mutagenic compounds such as nitrosamines [24].

Janicke et al. [25] showed that FA and $p$-CoA inhibit the proliferation of Caco-2 cells (43-75\%) after 2-3 days of treatment. These data are in agreement with Hudson et al. [23], where SW480 cells (colon cancer cells) treated with FA had reduced cell viability. Ferguson et al. [26] have confirmed antioxidant effects of hydroxycinnamic acids and extended their range of known activities to include protection against DNA and chromosome breakage, as well as modulation of the activity of specific enzymes previously associated with carcinogenesis.

Among the compounds studied, VA was the one that presented the lowest percent reduction in viability of HT-29 cells, an average percentage of $23 \%$. Ho et al. [27] in their results of cell viability assay, showed that vanillin exerts more cytolytic and cytostatic effect on HT-29 cells, while vanillic acid did not show any cytolytic or cytostatic effect at a concentration up to $500 \mu \mathrm{g} / \mathrm{mL}$.

Our results in MTT assay corroborate with the data obtained in cell counting with Neubauer chamber, where the compounds had the following order in the reduction of cell viability: 3,4-DHPAA > FA $>p-\mathrm{CoA}>$ VA. The data available in the literature and those found in our study suggest that mainly 3,4-DHPAA and FA may play a role as an inhibitor of cell viability and prevent the proliferation of human colon cancer cells.

Some authors have already studied the cytotoxicity of phenolic acids in normal and colon cancer cells and revealed that extracts of barley (Hordeum vulgare L.) as a rich source of different bioactive compounds inhibited the proliferation of cancer cells. The NR (neutral red) method study confirmed the low cytotoxic activity of the tested extracts to normal human colon epithelial cells (CCD 841 CoTr). The obtained results indicate a cancer chemopreventive potential of in colon carcinoma [28]. Subramanian et al. [29] showed that gallic acid (GA) treatment was non-toxic to normal cells. These results indicate that the phenolic compound GA has insignificant inhibitory activity against colon cancer cells even at a very high concentration. These data reinforce the results found by our work in silico analysis that demonstrated low toxicity of these compounds already described in animal models, with the exception of VA and FA.

Deregulated cell-cycle control is a fundamental aspect of cancer. Normal cells only proliferate in response to developmental or other mitogenic signals that indicate a requirement for tissue growth, whereas the proliferation of cancer cells proceeds essentially unchecked. Therefore, cancer cells proliferate because of defects in internal and external proliferation-inhibitory signals [30]. A limiting step in the cell cycle, which often is not regulated in cancer, is the progression of cells in the first stage $\left(\mathrm{G}_{1}\right)$ of the cycle to the $\mathrm{S}$ phase [31].

In Caco- 2 cells, FA and $p$-CoA decreased the proportion of cells in the $\mathrm{G}_{1}$ phase and increased the proportion of cells in the $S$ and $G_{2}$ phases. Treatment with FA significantly increased the length of the $S$ phase, while $p$-CoA did no. It was concluded that FA and $p$-CoA inhibited cell proliferation by presumably affecting different cell cycle phases, and this warrants further investigations because this inhibition may be one explanation for the diet-related protection against cancer [25].

In our study, cell cycle revealed that 3,4-DHPAA $(10 \mu \mathrm{M}$ and $100 \mu \mathrm{M})$ was able to induce an increase in the percentage of HT-29 cells in $G_{0} / G_{1}$ phase and decrease cells in $S$ and $G_{2} / M$ phases after $24 \mathrm{~h}$ of treatment compared to control. These data suggest cell cycle arrest in $\mathrm{G}_{0} / \mathrm{G}_{1}$ phase, where the 
cells are unable to reach the stage of mitosis and multiply. In this context, 3,4-DHPAA demonstrated an important effect on modulating cell cycle.

In this work, the cell cycle analysis of the VA and FA showed a decrease in the proportion of cells in the $\mathrm{G}_{0} / \mathrm{G}_{1}$ phase $(10 \mu \mathrm{M}$ and $100 \mu \mathrm{M}) 24 \mathrm{~h}$ after incubation. Also, VA did not promote an increase in the percentage of apoptotic cells (early and late apoptotic cells). Our data also revealed that FA decreased the percentage of viable cells $(10 \mu \mathrm{M})$, promoted an elongation $S$ phase and decreased $G_{2} / \mathrm{M}$ phase of the cell cycle, with an increase in the percentage of apoptotic cells (early and late apoptotic cells). At the concentration of $100 \mu \mathrm{M}$, this percentage of apoptotic cells was reduced and increased by non-apoptotic cells.

The understanding of the apoptotic mechanisms allows the development of new strategies in the treatment of cancer. Such strategies are based on the induction of death in tumor cells and a higher response to treatments with radiation and cytotoxic agents [32]. Apoptosis is the endpoint of at least one of the differentiation pathways of colon epithelial cells, a process that results in apoptotic cell death should also minimize the proliferative signal. In fact, in our model, the increase in apoptosis cell death rate after $24 \mathrm{~h}$ of incubation with $p$-CoA with an increase of cells in the $G_{2} / M$ phase of the cell cycle.

p-CoA and FA acids increased the relative apoptosis rate by 4.40 and 3.12 times, respectively, at the lowest concentrations tested. At high concentrations of $p$-CoA, FA and VA were able to increase the percentage of non-apoptotic cells, thus indicating a toxic effect of the high concentrations of these compounds. Previous studies related different molecular mechanisms of phenolic acids in apoptosis. VA significantly up regulated the expression and protein level of Procaspase-3, Procaspase-9, Bax and p53 when compared to control cells [33]. FA could inhibit the expression and activity of cytotoxic enzymes, including inducible nitric oxide synthase, caspases and cyclooxygenase-2 [34] and modulation of p53, Bax, and GADD45 [35]. Other authors hypothesize that the increased ROS generation may result in the activation of $\mathrm{p} 53$ in the $\mathrm{p}-\mathrm{CoA}$ treated colon cancer cells. This may in-turn would have caused the up-regulation of Bax and downregulation of Bcl2 which are the down-stream targets of p53 resulting in apoptosis [9]. In PC-12 cells, the combination of 3,4-dihydroxyphenylacetic acid and nitric oxide induced an early mitochondrial membrane potential dissipation accompanied by the release of cytochrome $c$ in both cases. Nitric oxide individually and in combination with 3,4-dihydroxyphenylacetic acid activate caspase-3 and caspase-9 [36]. It is likely that the pro-apoptotic effects promoted by phenolic acids in this work may be derived from the activation of caspases and Bax and modulation p53, already reported in other reports, however, but more studies are necessary to identify the mechanisms involved.

In vivo studies have also explored the anti-tumor activities of $p$-CoA and its conjugates. In a mouse tumor model induced by injection of RENCA cells, intraperitoneal administration of $p$-CoA for 1 week significantly decreased tumor volumes (by $53 \%$ ) and weights (by $40 \%$ ) by reducing angiogenesis within a tumor [37]. $p$-CoA also exerts moderate protection against 1,2-dimethylhydrazine-induced colon cancer in rats [38]. Cancerous rats fed with a high-fat diet containing $0.1 \% p$-CoA exhibited a decrease in colorectal carcinomas/rat from 2.5 to 2.0, the mean number of intestinal tumors/rat from 5.5 to 4.7 , and the total number of tumors in the small intestine from 0.87 to 0.45 tumors/rat [39].

Vanillic acid has been reported to exert a suppressive effect on the concanavalin A-induced liver injury due to their ROS (generated by activated NADPH oxidase in the lymphocytes) scavenging action. There is evidence that this compound significantly decreases the transaminase activity and suppress the disorganization of the hepatic sinusoids; they scavenge the ROS to suppress hepatocyte death. They also suppress the production of inflammatory cytokines, tumor necrosis factor (TNF)- $\alpha$, and interferon (IFN)- $\gamma$ in mice having liver inflammation. This phenolic compound is also found to dramatically suppress liver fibrogenesis in the chronic CCl4-treatment model [40].

According to Mancuso et al. [41], FA has a low degree of toxicity after oral administration. Some authors in their studies observed a reduction in mobility, piloerection and lacrimation in F344 rats treated with FA; in the case of single administration of FA higher than $1929 \mathrm{mg} / \mathrm{kg}$, the death of 
rats occurred during the first $24 \mathrm{~h}$ of the 14-day period of observation [42]. By contrast, death from gastrointestinal bleeding occurred $24 \mathrm{~h}$ from the administration. Finally, LD50s equal to $2445 \mathrm{mg} / \mathrm{kg}$ and $2113 \mathrm{mg} / \mathrm{kg}$ were calculated for male and female rats, respectively [43], whereas an acute LD50 of $3200 \mathrm{mg} / \mathrm{kg}$ was calculated in mice [44]. This low toxicity has been confirmed by numerous experimental studies [41].

Thus, although the in silico analysis shows low toxicity for these phenolic substances, the results of the in vitro analysis suggest that 3,4-DPHHA exercise the higher antiproliferative effect with low toxicity. The daily uptake of 3,4-DPHHA with food is $7.27 \mathrm{mg}$, and it is present in nanomolar concentrations in human plasma, so it is opening new perspectives for studies of this substance in vivo models for clinical implications.

\section{Materials and Methods}

\subsection{Standards and Chemicals}

Dulbecco's cell culture medium, bovine serum albumin and 3,4-DHPAA, $p$-CoA, VA and FA were purchased from Sigma-Aldrich Chemical Company (St. Louis, MO, USA). Fetal bovine serum was purchased from Laborclin (Campinas, São Paulo, Brazil). Tissue culture flasks and cell scrapers were purchased from Nunc (Roskilde, Denmark). All the chemicals were of analytical grade.

\subsection{Antioxidant Activity Analyses}

\subsubsection{Oxygen-Radical Absorbance Capacity Assay (ORAC)}

The ORAC procedure used an automated plate reader (SpectraMax i3x, Molecular Devices, San Jose, CA, USA) with 96 well plates $[45,46]$. Experiments were conducted in phosphate buffer $\mathrm{pH} 7.4$ at $37^{\circ} \mathrm{C}$. Peroxyl radical was generated using 2,2'-azobis (2-amidino-propane) dihydrochloride which was prepared fresh for each run. Fluorescein was used as the substrate. Fluorescence conditions were as follows: excitation at $485 \mathrm{~nm}$ and emission at $520 \mathrm{~nm}$. The standard curve was linear between 0 and $50 \mathrm{mM}$ Trolox. Results are expressed as $\mathrm{mEq}$ Trolox/L.

\subsubsection{Ferric Reducing Ability (FRAP)}

The extracts were measured for antioxidant activity by FRAP according to Bauer et al. [47]. Aliquots of $2.7 \mathrm{~mL}$ of TPTZ reagent (ferric 2,4,6-tripyridyl-s-triazine) were mixed with $0.5 \mathrm{~mL}$ of sample. After $30 \mathrm{~min}$ at $37^{\circ} \mathrm{C}$ temperature, the absorbance was read at $595 \mathrm{~nm}$. The antioxidant capacity (FRAP) was expressed as $\mathrm{Fe}^{3+}$ equivalents ( $\mu \mathrm{mol}$ ferrous sulfate/ $\mu \mathrm{mol}$ of compound).

\subsubsection{DPPH Assay}

Aliquots of $0.5 \mathrm{~mL}$ of the extracts were mixed with $2.5 \mathrm{~mL}$ DPPH methanolic solution $(0.06 \mathrm{mM})$ and allowed to react for half an hour, in the dark. Measurements were performed at $515 \mathrm{~nm}$ applying a Turner $^{\circledR} 340$ spectrophotometer (Barnstead/Thermolyne, Dubuque, IA, USA). The analysis was performed in triplicates and the decline in the DPPH radical absorbance concentration caused by the samples was measured. The results expressed as the percentage reduction of the DPPH [48].

\subsubsection{Trolox Equivalent Antioxidant Capacity (ABTS/TEAC)}

The TEAC ${ }^{+}$cation was prepared by mixing a TEAC stock solution ( $7 \mathrm{mM}$ in water) with $2.45 \mathrm{mM}$ potassium persulphate. This mixture was allowed to stand for $16 \mathrm{~h}$ at room temperature until the reaction was completed and the absorbance was stable. The antioxidant capacity assay was carried out by the improved ABTS/TEAC method of Bauer et al. [47]. TEAC solution ( $2.5 \mathrm{~mL})$ was added to samples or commercial antioxidant (Trolox) and mixed thoroughly. Absorbance was recorded at $734 \mathrm{~nm}$ for $6 \mathrm{~min}$. Results were calculated as $\mu \mathrm{mol}$ Trolox/ $\mu \mathrm{mol}$ and $\mu \mathrm{mol}$ ascorbic acid/ $\mu \mathrm{mol}$. 


\subsection{Cell Culture and Treatment Protocol}

Human colon adenocarcinoma cell line (HT-29) was obtained and certified from the Rio de Janeiro Cell Bank (Inmetro, Rio de Janeiro, Brazil) that have certified their identity and quality. HT-29 cells were plated in $25 \mathrm{~cm}^{2}$ tissue culture flasks, $5.0 \times 10^{6}$ cells/flask, and maintained routinely in Dulbecco's medium supplemented (DMEM) with $10 \%$ fetal bovine serum and $2 \mathrm{~g} / \mathrm{L}$ HEPES buffer, $\mathrm{pH}=7.4$, under $5 \% \mathrm{CO}_{2}$ atmosphere. Cells were passaged at $70-80 \%$ confluence, about twice a week by trypsinization. Cells were seeded at $2.0 \times 10^{4}$ cells $/ \mathrm{cm}^{2}$ in 6 -multiwell plates $(2 \mathrm{~mL}$ of standard culture medium) for Cell Counting with Neubauer Chamber, cell cycle progression, and apoptosis analyses and in 96-multiwell plates ( $200 \mathrm{~mL}$ of standard culture medium) for cell viability analyses. After $24 \mathrm{~h}$, the culture medium was removed and 3,4-DHPAA $p$-CoA, VA and FA dissolved in standard medium culture in concentrations ranging from $0.1 \mu \mathrm{M}$ to $100 \mu \mathrm{M}$ were added. The controls (cells maintained in DMEM without (3,4-DHPAA $p$-CoA, VA and FA) were included on each plate. For cell cycle and apoptosis analyses, cells were treated with $10 \mu \mathrm{M}$ and $100 \mu \mathrm{M}$ of 3,4-DHPAA $p$-CoA, VA and FA for $24 \mathrm{~h}$. For cell counting with a Neubauer chamber, cells were incubated with $1 \mu \mathrm{M}$ and $10 \mu \mathrm{M}$ of each compound for $24 \mathrm{~h}$. For cell viability analyses cells were treated with concentrations ranging from $0.1 \mu \mathrm{M}$ to $100 \mu \mathrm{M}$ of each compound for $24 \mathrm{~h}$.

\subsection{Cell Viability Assays}

\subsubsection{MTT Assay}

The status of cancer cell line viability was determined by MTT (3-[4,5-dimethylthiazol-2-yl]-2,5diphenyltetrazolium bromide; thiazolyl blue) assay (Sigma, New York, NY, USA) which substance is a pale yellow substrate that is reduced by living cells to yield a dark blue formazan product. This requires active mitochondria, and even recently dead cells do not reduce significant amounts of MTT. Exponentially growing cells were adjusted to $2.0 \times 10^{4} / \mathrm{cm}^{2}$ with DMEM, plated in 96-well plates (Corning, Tewksbury, MA, USA) at $200 \mu \mathrm{L} /$ well and incubated for $24 \mathrm{~h}$ according to the routine procedure. The cells were then incubated with 3,4-DHPAA $p$-CoA, VA and FA $(0.1 \mu \mathrm{M}$ to $100 \mu \mathrm{M})$ for $24 \mathrm{~h}$. Each well was also incubated with MTT (10 $\mu \mathrm{L} /$ well; $5 \mathrm{~g} / \mathrm{mL})$ for $4 \mathrm{~h}$. After $85 \mu \mathrm{L} /$ well the liquid was removed and $50 \mu \mathrm{L} /$ well sodium dodecyl sulfate was added to dissolve the solid residue. Finally, the absorbance was measured using a microplate reader (POLARIS-CELER ${ }^{\circledR}$, Celer Biotecnologia, Minas Gerais, BH, Brazil) at $570 \mathrm{~nm}$. The cell proliferation inhibition rate was calculated using the following formula: Cell viability (relative $\%$ of control $)=(1-$ average value of experimental group/average value of control group) $\times 100 \%$.

\subsubsection{Cell Counting with Neubauer Chamber}

Cells were grown to about $80 \%$ confluence in 6-well plates and treated for $24 \mathrm{~h}$ with 3,4-DHPAA $p$-CoA, VA and FA $(1.0 \mu \mathrm{M}$ and $10 \mu \mathrm{M})$. Adherent and non-adherent cells were collected and viability was assessed by mixing aliquots of cell suspensions with equal volumes of $0.4 \%$ trypan blue (GibcoBRL, Tokyo, Japan). Cells that accumulated the dye were considered dead.

\subsection{Cell Cycle Analysis}

Cells were rinsed briefly with calcium and magnesium-free phosphate-buffered saline and detached with trypsin at room temperature. After centrifugation, the cells were washed twice with phosphate-buffered saline, cells were resuspended in $1.0 \mathrm{~mL}$ of ice-cold Vindelov solution [49], containing $0.1 \%$ Triton X-100, $0.1 \%$ citrate buffer and $0.1 \mathrm{mg} / \mathrm{mL}$ RNase, and $50 \mathrm{mg} / \mathrm{mL}$ propidium iodide (Sigma Chemical Co., Saint Louis, MO, USA). After 15 min of incubation, the cell suspension was analyzed for DNA content by flow cytometry using a FACS Calibur flow cytometer (Becton Dickinson, Mountain View, CA, USA). The relative proportions of cells with DNA content diploid G0-G1 (2n), S phase ( $>2 \mathrm{n}$ but $<4 \mathrm{n}$ ), and $\mathrm{G}_{2} / \mathrm{M}$ phase ( $\left.4 \mathrm{n}\right)$ were acquired and analyzed using Cell-Quest and WinMDI 2.9, respectively. The percentage of cell population at a particular phase was estimated 
with FlowJo software following the acquisition of 30,000 events. Cell dissociation procedure does not affect fluorescence under the experimental conditions that were used in this study or in any others of which we are aware. Nuclei of viable cells were gated according to FL-2W $\times$ FL2-A relation. Doublets and DNA fragmented nuclei were excluded from the analysis.

\subsection{Apoptosis}

To measure the rate of apoptosis, control and phenolic acids-treated cells were collected, washed twice with ice-cold PBS and resuspended in $500 \mu \mathrm{L}$ binding buffer (BD, Pharmigen, San Diego, CA, USA). Next, $5 \mu \mathrm{L}$ annexin V-fluorescein isothiocyanate (FITC) and $5 \mu \mathrm{L}$ propidium iodide (PI) were added and the cells were incubated for $15 \mathrm{~min}$ at room temperature in the dark. FITC and PI staining was analyzed to determine the apoptotic rate. The percentage of total apoptotic cells was calculated by adding the percentages of early apoptotic gated cells (annexin $\mathrm{V}^{+} / \mathrm{PI}^{-}$) and late apoptotic gated cells (annexin $\mathrm{V}^{+} / \mathrm{PI}^{+}$). The reading was held on the flow cytometer (BD Biosciences, Franklin Lakes, NJ, USA), following the acquisition of 20,000 events on CellQuest, and the data analyzed using the FlowJo software (FlowJo v.X).

\subsection{In Silico Approach}

We used a modular toxicological predictive QSAR framework algorithm (Lazy Structure-Activity Relationships or LAZAR in silico toxicology, https: / lazar.in-silico.ch/predict) [50] based on similarity of chemical alerts. LAZAR is a modular framework for predictive toxicology. Similar to the read across procedure in toxicological risk assessment, lazar creates local QSAR (quantitative structure-activity relationship) models for each compound to be predicted. Model developers can choose between a large variety of algorithms for descriptor calculation and selection, chemical similarity indices, and model building [50]. To perform the toxicological prediction in LAZAR, we designed phenolic acid chemical structure using ChemDraw and obtained the SMILE string. With the SMILE string, we predicted absorption, distribution, metabolism, excretion, and toxicological parameters (ADMET) based on QSAR similarity, using the pharmacokinetic algorithm pkCSM (http:/ / bleoberis.bioc.cam.ac. $\mathrm{uk} / \mathrm{pkcsm} /$ prediction) [51].

\subsection{Statistical Analysis}

The results presented are the mean and the corresponding standard deviation of three independent experiments performed in triplicate $(n=9)$. Data were analyzed using GraphPad Prism statistical software (version 5.04, GraphPad Software Inc., San Diego, CA, USA). The univariate analysis of variance (ANOVA) with the Tukey post-test at a $95 \%$ confidence level was used to test cell viability, cell cycle and apoptosis rate.

\section{Conclusions}

In conclusion, the data presented in this work showed that phenolic acids might play an essential role in reducing cell viability, modulating the cell cycle and controlling tumor progression through induction of apoptosis. Few studies investigated the effect of 3, 4-DHPAA, $p$-CoA, VA and FA in colon cancer cells, but what has been reported so far show an important role of these compounds as potent antioxidants and can be used in the prevention of various diseases among this cancer. 3,4-DHPAA seems to be the substance with the highest potential for in vivo studies, opening thus a series of views on the use of these compounds in the prevention and treatment of colon cancer.

Author Contributions: Conceptualization, L.d.S.R., M.M., J.F.d.M. and A.J.T.; Methodology, L.d.S.R., N.A.J., N.d.C.P.S, J.F.d.M., and A.J.T. Data Curation, L.d.S.R., N.A.J., N.d.C.P.S, J.F.d.M., and A.J.T. Writing-Original Draft Preparation, L.d.S.R., M.M., J.F.d.M. and A.J.T.; Writing-Review \& Editing, L.d.S.R., M.M., J.F.d.M. and A.J.T.

Funding: This research was funded by FAPERJ grant number 228434 and 227094.

Conflicts of Interest: The authors declare no conflict of interest. 
Availability of Data and Materials: All the processed data are presented in the article. Information on raw data and materials are available from the corresponding authors upon request.

\section{References}

1. Siegel, R.; Naishadham, D.; Jemal, A. Cancer statistics. Cancer J. Clin. 2013, 63, 11-30. [CrossRef] [PubMed]

2. Robertson, J.H.P.; Sarkar, S.; Yang, S.Y.; Seifalian, A.M.; Winslet, M.C. In vivo models for early development of colorectal liver metastasis. Int. J. Exp. Pathol. 2008, 89, 1-12. [CrossRef] [PubMed]

3. Olthof, M.R.; Hollman, P.C.; Katan, M.B. Chlorogenic acid and caffeic acid are absorbed in humans. J. Nutr. 2001, 131, 66-71. [CrossRef] [PubMed]

4. Latifah, S.Y.; Armania, N.; Tze, T.H.; Azhar, Y.; Nordiana, A.H.; Norazalina, S. Germinated brown rice (GBR) reduces the incidence of aberrant crypt foci with the involvement of $\beta$-catenin and $\mathrm{CO}_{\mathrm{X}-2}$ in azoxymethane-induced colon cancer in rats. Nutr. J. 2010, 9, 1-8. [CrossRef] [PubMed]

5. Gunasekaran, S.; Venkatachalam, K.; Jeyavel, K.; Namasivayam, N. Protective effect of p-methoxycinnamic acid, an active phenolic acid against 1,2-dimethylhydrazine-induced colon carcinogenesis: Modulating biotransforming bacterial enzymes and xenobiotic metabolizing enzymes. Mol. Cell. Biochem. 2014, 394, 187-198. [CrossRef] [PubMed]

6. Liu, R.H. Potential synergy of phytochemicals in cancer prevention: Mechanism of action. J. Nutr. 2004, 134, 3479S-3485S. [CrossRef] [PubMed]

7. Senawong, T.; Khaopha, S.; Misuna, S.; Komaikul, J.; Senawong, G.; Wongphakham, P.; Yunchalard, S. Phenolic acid composition and anticancer activity against human cancer cell lines of the commercially available fermentation products of Houttuynia cordata. Sci. Asia 2014, 40, 420-427. [CrossRef]

8. Janicke, B.; Hegardt, C.; Krogh, M.; Önning, G.; Åkesson, B.; Cirenajwis, H.M.; Oredsson, S.M. The Antiproliferative Effect of Dietary Fiber Phenolic Compounds Ferulic Acid and $p$-Coumaric Acid on the Cell Cycle of Caco-2 Cells. Nutr. Cancer 2011, 63, 611-622. [CrossRef] [PubMed]

9. Jaganathan, S.K.; Supriyanto, E.; Mandal, M. Events associated with apoptotic effect of $p$-Coumaric acid in HCT-15 colon cancer cells. World J. Gastroenterol. 2013, 19, 7726-7734. [CrossRef] [PubMed]

10. Swizdor, A.; Panek, A.; Milecka-Tronina, N.; Kołek, T. Biotransformations utilizing $\beta$-oxidation cycle reactions in the synthesis of natural compounds and medicines. Int. J. Mol. Sci. 2012, 13, 16514-16543. [CrossRef] [PubMed]

11. Kim, S.-J.; Kim, M.-C.; Um, J.-Y.; Hong, S.-H. The Beneficial Effect of Vanillic Acid on Ulcerative Colitis. Molecules 2010, 15, 7208-7217. [CrossRef] [PubMed]

12. Xue, H.; Xie, W.; Jiang, Z.; Wang, M.; Wang, J.; Zhao, H.; Zhang, X. 3,4-Dihydroxyphenylacetic acid, a microbiota-derived metabolite of quercetin, attenuates acetaminophen (APAP)-induced liver injury through activation of Nrf-2. Xenobiotica 2016, 46, 931-939. [CrossRef] [PubMed]

13. Raneva, V.; Shimasaki, H.; Ishida, Y.; Ueta, N.; Niki, E. Antioxidative activity of 3,4-dihydroxyphenylacetic acid and caffeic acid in rat plasma. Lipids 2001, 36, 1111-1116. [CrossRef] [PubMed]

14. Rosa, L.S.; Silva, N.J.A.; Soares, N.C.P.; Monteiro, M.C.; Teodoro, A.J. Anticancer Properties of Phenolic Acids in Colon Cancer-A Review. J. Nutr. Food Sci. 2016, 06, 1-7. [CrossRef]

15. Fiuza, S.M.; Gomes, C.; Teixeira, L.J.; Girão Da Cruz, M.T.; Cordeiro, M.N.D.S.; Milhazes, N.; Borges, F.; Marques, M.P.M. Phenolic acid derivatives with potential anticancer properties-a structure-activity relationship study. Part 1: Methyl, propyl and octyl esters of caffeic and gallic acids. Bioorg. Med. Chem. 2004, 12, 3581-3589. [CrossRef] [PubMed]

16. Monagas, M.; Khan, N.; Andrés-Lacueva, C.; Urpí-Sardá, M.; Vázquez-Agell, M.; Lamuela-Raventós, R.M.; Estruch, R. Dihydroxylated phenolic acids derived from microbial metabolism reduce lipopolysaccharide-stimulated cytokine secretion by human peripheral blood mononuclear cells. Br. J. Nutr. 2009, 102, 201-206. [CrossRef] [PubMed]

17. Tai, A.; Sawano, T.; Ito, H. Antioxidative Properties of Vanillic Acid Esters in Multiple Antioxidant Assays. Biosci. Biotechnol. Biochem. 2012, 76, 314-318. [CrossRef] [PubMed]

18. Kiliç, I.; Yesiloglu, Y. Spectroscopic studies on the antioxidant activity of p-coumaric acid. Spectrochim. Acta Part A Mol. Biomol. Spectrosc. 2013, 115, 719-724. [CrossRef] 
19. Gao, K.; Xu, A.; Krul, C.; Venema, K.; Liu, Y.; Niu, Y.; Lu, J.; Bensoussan, L.; Seeram, N.P.; Heber, D.; et al. Of the Major Phenolic Acids Formed during Human Microbial Fermentation of Tea, Citrus, and Soy Flavonoid Supplements, Only 3,4-dihydroxyphenylacetic Acid Has Antiproliferative Activity. J. Nutr. 2006, 136, 52-57. [CrossRef] [PubMed]

20. Manthey, J.A.; Guthrie, N. Antiproliferative activities of citrus flavonoids against six human cancer cell lines. J. Agric. Food Chem. 2002, 50, 5837-5843. [CrossRef] [PubMed]

21. Henning, S.M.; Wang, P.; Abgaryan, N.; Vicinanza, R.; De Oliveira, D.M.; Zhang, Y.; Lee, R.; Carpenter, C.L.; William, J. Phenolic acid concentrations in plasma and urine from men consuming green or black tea and potential chemopreventive properties for colon cancer. Mol. Nutr. Food Res. 2013, 57, 483-492. [CrossRef] [PubMed]

22. Mori, H.; Kawabata, K.; Yoshimi, N.; Tanaka, T.; Murakami, T.; Okada, T.; Murai, H. Chemopreventive effects of ferulic acid on oral and rice germ on large bowel carcinogenesis. Anticancer Res. 1999, 19, 3775-3778. [PubMed]

23. Hudson, E.A.; Dinh, P.A.; Kokubun, T.; Simmonds, M.S.; Gescher, A. Characterization of potentially chemopreventive phenols in extracts of brown rice that inhibit the growth of human breast and colon cancer cells. Cancer Epidemiol. Biomark. Prev. 2000, 9, 1163-1170.

24. Andreasen, M.F.; Kroon, P.A.; Williamson, G.; Garcia-Conesa, M.-T. Intestinal release and uptake of phenolic antioxidant diferulic acids. Free Radic. Biol. Med. 2001, 31, 304-314. [CrossRef]

25. Janicke, B.; Onning, G.; Oredsson, S.M. Differential effects of ferulic acid and $p$-coumaric acid on S phase distribution and length of $S$ phase in the human colonic cell line Caco-2. J. Agric. Food Chem. 2005, 53, 6658-6665. [CrossRef] [PubMed]

26. Ferguson, L.R.; Zhu, S.; Harris, P.J. Antioxidant and antigenotoxic effects of plant cell wall hydroxycinnamic acids in cultured HT-29 cells. Mol. Nutr. Food Res. 2005, 49, 585-593. [CrossRef] [PubMed]

27. Ho, K.; Yazan, L.S.; Ismail, N.; Ismail, M. Apoptosis and cell cycle arrest of human colorectal cancer cell line HT-29 induced by vanillin. Cancer Epidemiol. 2009, 33, 155-160. [CrossRef] [PubMed]

28. Czerwonka, A.; Kawka, K.; Cykier, K.; Lemieszek, M.; Rzeski, W. Evaluation of anticancer activity of water and juice extracts of young Hordeum vulgare in human cancer cell lines HT-29 and A549. Ann. Agric. Environ. Med. 2017, 24, 345-349. [CrossRef] [PubMed]

29. Subramanian, A.P.; Jaganathan, S.K.; Mandal, M.; Supriyanto, E.; Muhamad, I.I. Gallic acid induced apoptotic events in HCT-15 colon cancer cells. World J. Gastroenterol. 2016, 22, 3952-3961. [CrossRef] [PubMed]

30. Nakayama, K.I.; Nakayama, K. Ubiquitin ligases: Cell-cycle control and cancer. Nat. Rev. Cancer 2006, 6, 369-381. [CrossRef] [PubMed]

31. Gloria, N.F.; Soares, N.; Brand, C.; Oliveira, F.L.; Borojevic, R.; Teodoro, A.J. Lycopene and $\beta$-carotene induce cell-cycle arrest and apoptosis in human breast cancer cell lines. Anticancer Res. 2014, 34, 1377-1386. [PubMed]

32. Soares, N.C.P.; Machado, C.L.; Trindade, B.B.; Lima, I.C.C.; Gimba, E.R.P.; Teodoro, A.J.; Takiya, C.; Borojevic, R. Lycopene extracts from different tomato-based food products induce apoptosis in cultured human primary prostate cancer cells and regulate TP53, Bax and Bcl-2 transcript expression. Asian Pac. J. Cancer Prev. 2017, 18, 339-345. [CrossRef] [PubMed]

33. Kumar, P.P.B.S.; Ammani, K.; Azhar, M.; Jaya, G. Vanillic acid induces oxidative stress and apoptosis in nonsmall lung cancer cell line. Int. J. Recent Sci. Res. 2013, 4, 1077-1083.

34. Zhang, X.; Lin, D.; Jiang, R.; Li, H.; Wan, J.; Li, H. Ferulic acid exerts antitumor activity and inhibits metastasis in breast cancer cells by regulating epithelial to mesenchymal transition. Oncol. Rep. 2016, 36, 271-278. [CrossRef] [PubMed]

35. Wang, T.; Gong, X.; Jiang, R.; Li, H.; Du, W.; Kuang, G. Ferulic acid inhibits proliferation and promotes apoptosis via blockage of PI3K/Akt pathway in osteosarcoma cell. Am. J. Transl. Res. 2016, 8, 968-980. [PubMed]

36. Nunes, C.; Almeida, L.; Laranjinha, J. 3,4-dihydroxyphenylacetic acid (DOPAC) modulates the toxicity induced by nitric oxide in PC-12 cells via mitochondrial dysfunctioning. Neurotoxicology 2008, 29, 998-1007. [CrossRef] [PubMed]

37. Kong, C.-S.; Jeong, C.-H.; Choi, J.-S.; Kim, K.-J.; Jeong, J.-W. Antiangiogenic Effects of $p$-Coumaric Acid in Human Endothelial Cells. Phytother. Res. 2012, 199, 317-323. [CrossRef] 
38. Femia, A.P.; Caderni, G.; Vignali, F.; Salvadori, M.; Giannini, A.; Biggeri, A.; Gee, J.; Przybylska, K.; Cheynier, V.; Dolara, P. Effect of polyphenolic extracts from red wine and 4-OH-coumaric acid on 1,2-dimethylhydrazine-induced colon carcinogenesis in rats. Eur. J. Nutr. 2005, 44, 79-84. [CrossRef] [PubMed]

39. Singletary, K.W.; Stansbury, M.J.; Giusti, M.; van Breemen, R.B.; Wallig, M.; Rimando, A. Inhibition of Rat Mammary Tumorigenesis by Concord Grape Juice Constituents. J. Agric. Food Chem. 2003, 51, 7280-7286. [CrossRef] [PubMed]

40. Bhilare, N.V.; Dhaneshwar, S.S.; Mahadik, K.R. Phenolic acid-tethered isoniazid for abrogation of drug-induced hepatotoxicity: Design, synthesis, kinetics and pharmacological evaluation. Drug Deliv. Transl. Res. 2018, 8, 770-779. [CrossRef] [PubMed]

41. Mancuso, C.; Santangelo, R. Ferulic acid: Pharmacological and toxicological aspects. Food Chem. Toxicol. 2014, 65, 185-195. [CrossRef] [PubMed]

42. Tada, Y.; Tayama, K.; Aoki, N. Acute oral toxicity of ferulic acid, natural food additive, in rats. Ann. Rep. Tokyo Metr. 1999, 3, 311-313.

43. Ou, S.; Kwok, K.C. Ferulic acid: Pharmaceutical functions, preparation and applications in foods. J. Sci. Food Agric. 2004, 84, 1261-1269. [CrossRef]

44. Wang, B.-H.; Ou-Yang, J.-P. Pharmacological actions of sodium ferulate in cardiovascular system. Cardiovasc. Drug Rev. 2005, 23, 161-172. [CrossRef] [PubMed]

45. Ou, B.; Hampsch-Woodill, M.; Prior, R.L. Development and Validation of an Improved Oxygen Radical Absorbance Capacity Assay Using Fluorescein as the Fluorescent Probe. J. Agric. Food Chem. 2001, 49, 4619-4626. [CrossRef] [PubMed]

46. Prior, R.L.; Hoang, H.; Gu, L.; Wu, X.; Bacchiocca, M.; Howard, L.; Hampsch-Woodill, M.; Huang, D.; Ou, B.; Jacob, R. Assays for Hydrophilic and Lipophilic Antioxidant Capacity (oxygen radical absorbance capacity (ORACFL)) of Plasma and Other Biological and Food Samples. J. Agric. Food Chem. 2003, 51, 3273-3279. [CrossRef] [PubMed]

47. Bauer, D.; De Abreu, J.P.; Oliveira, H.S.S.; Goes-Neto, A.; Koblitz, M.G.B.; Teodoro, A.J. Antioxidant Activity and Cytotoxicity Effect of Cocoa Beans Subjected to Different Processing Conditions in Human Lung Carcinoma Cells. Oxid. Med. Cell. Longev. 2016, 2016, 7428515. [CrossRef] [PubMed]

48. Brand-Williams, W.; Cuvelier, M.E.; Berset, C. Use of a free radical method to evaluate antioxidant activity. LWT-Food Sci. Technol. 1995, 28, 25-30. [CrossRef]

49. Vindelov, L.L. Flow microfluorometric analysis of nuclear DNA in cells from solid tumors and cell suspensions. A new method for rapid isolation and straining of nuclei. Virchows Arch. B Cell Pathol. 1977, 24, 227-242. [PubMed]

50. Maunz, A.; Gütlein, M.; Rautenberg, M.; Vorgrimmler, D.; Gebele, D.; Helma, C. lazar: A modular predictive toxicology framework. Front. Pharmacol. 2013, 4, 38. [CrossRef] [PubMed]

51. Pires, D.E.V.; Blundell, T.L.; Ascher, D.B. pkCSM: Predicting Small-Molecule Pharmacokinetic and Toxicity Properties Using Graph-Based Signatures. J. Med. Chem. 2015, 58, 4066-4072. [CrossRef] [PubMed]

Sample Availability: Samples of the compounds are not available from the authors.

(C) 2018 by the authors. Licensee MDPI, Basel, Switzerland. This article is an open access article distributed under the terms and conditions of the Creative Commons Attribution (CC BY) license (http://creativecommons.org/licenses/by/4.0/). 